\title{
GREEN RECRUITMENT STRATEGY ON THE ECONOMIC SUSTAINABILITY OF FINANCIAL INSTITUTIONS IN NIGERIA
}

\author{
Eze Ijeoma Chinenye \\ Department of Business Administration \\ Faculty of Management Sciences \\ Enugu State University of Science and Technology, Enugu
}

The study focused on the" green recruitment strategy on the economic sustainability of financial institutions in Nigeria". The specific objectives include to: examine the effect of email application strategy on the low cost of financial institutions in Nigeria; evaluate the effect of online application form strategy on the high employee engagement of financial institutions in Nigeria and to investigate the effect if global talent pool on the high employee retention of financial institutions in Nigeria.Survey approach was adopted because the respondents were spread all over the Institutions that make up the study organization. The areas of study includes: the Zenith bank plc. United banks of Africa (UBA), Ecobank, and First bank plc. The idea of choosing Enugu state was the proximity of these banks in Enugu metropolis. Two sources of data were utilized in the study. They included primary and secondary sources. Out of a population of 560 staff and students, 218 staff was sampled. The sample size of 218 was chosen after applying the Freund and William's formula for the determination of adequate sample size. 214 staff returned the questionnaire and accurately filled. That gave 97 percent response rate. The closed-ended questionnaire was utilized. The validity of the instrument was tested using content analysis and the result was good. The reliability was tested using the Pearson correlation coefficient(r). It gave a reliability coefficient of 0.89 which was also good. The data were analyzed using regression analysis and f-statistical tool aid of Special Package of Statistical Software (SPSS). The hypotheses were tested using f-statistics (ANOVA) tool. The result of the study showed that e-mail application forms strategy had positive significant effect on the low cost of financial institutions in Nigeria $\mathrm{F}(\mathrm{n}=218)=40.654, \mathrm{P}<0.05$; online application forms strategy has positive significant effect on the high employee engagement of financial institution in Nigeria. $\mathrm{F}(\mathrm{n}=$ $218)=57.857, \mathrm{P}<0.05$; global talent pool application forms strategy has positive significant effect on the high employee retention of financial institutions in NigeriaF $(n=218)=53.666$, $\mathrm{P}<0.05$. The study concludes that e-mail application forms strategy on the low cost; online application forms strategy on the high employee engagement and global talent pool application forms strategy had positive significant effect on the high employee retention of financial institutions in Nigeria. The study recommended that management team should show recognition and appreciation for work well done as this may assist in employee retention and enhance the culture of the financial institutions.

Keywords: Green recruitment strategy, economic sustainability, financial institution. 


\subsection{Background of the Study}

\section{INTRODUCTION}

Financial institutions are key players in any country's long-term sustainable development goals. Sustainable development as a concept may be strange to banks because they provide intangible services (Rwakiseta, 2018). However, there are only two ways through which banks can have an influence on society direct ldirect. These are the environment and the economy, through which sector players can have an impact because of their daily operations, while indirect influence is about bank products and services rendered to customers. Although banks make small margins from reducing direct footprints, the actual control is through the asset side and client's projects the banks intend to finance. Gone are the days when banks preferred defensive banking as a way of avoiding additional costs through social and environmental impact (Rwakiseta, 2018).Despite its temporary economic setbacks, Nigeria needs substantial investment in physical and human infrastructure and social capital (see Blignaut \& Parsons, 2005).

Green recruitment is the process of hiring candidates with knowledge, skills, approaches, and behaviors that identify with environmental management systems within an organization. It is a system where more accent is provided to the environmental aspects and making it a major element of the organization, as the society is nowadays more worried towards the existing environmental issues. Moreover, today the business environment has been forced to undergo swift changes and the organizations which do not realize and acclimate those changes on time find very hard chances to survive (Aranganathan, 2018). Sustainable banking can be understood to mean the decision by banks to deliver products and services to customers, who take into concern the environmental and social impacts of their activities (Rwakiseta, 2018). The goal of the study is to evaluate green recruitment strategy on the economic sustainability of financial institutions in Nigeria.

\subsection{Statement of Problems}

Recruitment is the most important function of HR, which entails attracting the right person for the right job at the right time. Green HR Practices has emerged from organizations which focuses on protecting the environment and maintaining ecological balance. Green HR practices can become an active partner for the organization to achieve various socioeconomic objectives of the organization.

The major challenge for the human resource professionals is the understanding of the scope and depth of green HRM in the process of transformation of their organizations to green entities. Ultimately, this effort leads the organization to perform better in terms of environment. Stating differently, greening of HRM functions will eventually decrease negative environmental effects of the organization and helps in enhancing the positive environmental effects of the organization. Training and development, recruitment, and learning play key role in improving environmental performance of the organization.

Given the present situation the organizations have to find out ways and techniques to deal with challenges facing green recruitment besides dealing with the economic issues. In order to attain success within the green recruitment on the economic sustainability and to facilitate attainment of profit by the organizations nowadays have to concentrate on social and environmental factors along with economical and financial factors. Therefore, the study evaluate on green recruitment strategy on economic sustainability of the financial institution.

\subsection{Objectives of the Study}

The broad objective of the study was to evaluate the green recruitment strategy on economic sustainability of financial institutions in Nigeria. The specific objectives are to: 
i. Examine the effect of e-mail application strategy on the low cost of financial institutions in Nigeria.

ii. Evaluate the effect of online application form strategy on the high employee engagement of financial institutions in Nigeria.

iii. Investigate the effect if global talent pool on the high employee retention of financial institutions in Nigeria.

\subsection{Research Questions}

The following research questions guided the study.

i. What is the effect of e-mail application strategy on the low cost of financial institutions in Nigeria?

ii. What is the effect of online application form strategy on the high employee engagement of financial institutions in Nigeria?

iii. What is the effect if global talent pool on the high employee retention of financial institutions in Nigeria?

\subsection{Statement of Hypotheses}

The following alternate hypotheses guided the study.

i. E-mail application strategy has positive effect on the low cost of financial institutions in Nigeria.

ii. Online application form strategy has positive effect on the high employee engagement of financial institutions in Nigeria.

iii. Global talent pool has positive effect on the high employee retention of financial institutions in Nigeria.

\subsection{Significance of the Study}

Green recruitment are of crucial importance in creating, practicing and maintaining environmental related employees' innovative behaviors along right attitude of greening. It is difficult to create and maintain sustainable environmental performance without proper green recruitment. Therefore, this is stated that the comprehension of the scope and depth of green recruitment by the organizations is significant and helps organizations to perform better in terms of environment than before.

\section{Review of Related Literature}

\subsection{Conceptual Framework}

\subsubsection{Green Recruitment Strategy}

Organizations are becoming more and more aware of the importance of practicing sustainable development in the work force, both for the reputation it creates as an environmentally responsible company, as well as for the financial benefits that permeate throughout the establishment. As your organization becomes more aware of the benefits of an environmentally-friendly work place, it's important to also introduce a green recruiting strategy with a strong focus on reducing the HR department's carbon footprint. In today's day and age of sustainability, the new workforce is pushing for employers to consider green options and create a sustainable workforce (Smith, 2014). Recruitment refers to the process of attracting, screening, and selecting qualified people for a job at an organization or firm. For some components of the recruitment process, mid- and large-size organizations often retain professional recruiters or outsource some of the process to recruitment agencies (Sharma and Robin, 2011). 
Green recruitment strategy means a paper-free recruitment process with a minimal environmental impact. Applications are invited through online mediums like e-mail, online application forms or the Global Talent Pool. If possible, telephone or video-based interviews are conducted to minimize any travel-related environmental impact. Green Recruitment is active in the field of professional recruitment, with a view to meeting the growing needs for experts in the areas of renewable energy, climate change and sustainable development. Services range from contract recruitment to executive search. Whether one is looking for the brightest emerging talent or the most established industry leaders, Green Recruitment is longterm partner in environmental recruitment for recruiters(Sharma and Robin, 2011).

\subsubsection{Financial Institution}

A financial institution (FI) is a company engaged in the business of dealing with financial and monetary transactions such as deposits, loans, investments, and currency exchange. Financial institutions encompass a broad range of business operations within the financial services sector including banks, trust companies, insurance companies, brokerage firms, and investment dealers. Virtually everyone living in a developed economy has an ongoing or at least periodic need for the services of financial institutions(Adam, 2019). A financial institution is basically an establishment that conducts financial transactions such as investments, loans and deposits.There are five main types of financial institutions (David, 2019).

1.Commercial banks

2. Investment Banks

3. Insurance Company

4. Brokerage

5. Investment Company (David, 2017)

\subsubsection{Economic Sustainability}

Over the past few decades, the financial sector has sought to positively contributing to sustainable development through innovative products and services. However, in its businessas-usual the financial sector continues to contribute to military interventions, environmental degradation, growing disparity of incomes, de-coupling of finance and real economy, and global economic crises (Olaf, 2014). Economic sustainability is fundamental to the development of stable communities functioning within healthy environments. Adding value to existing industries, developing sound parameters for their sustainable growth, or making them more efficient, are other ways of contributing to economic sustainability. Finance is at the very heart of an essential shift to more sustainable development, based on a more inclusive and sustainable economy (Olaf, 2014).

Financial institutions holds a unique position with regard to sustainable economic development because of their intermediation function between depositors and borrowers. Sustainability is now increasingly recognized as central to the growth of emerging market economies. For the banking sector, this represents both a demand for greater social and environmental responsibility as well as a new landscape of business opportunity (Mihir, Abdus and Shahriar, 2015). Recently, the banks began to realize the major impact of the sustainable development over the way of ulterior development of the society and, implicitly over the way of creating the banking value in the future. Therefore, sustainability is about ensuring long term business success, while contributing towards economic and social development, a healthy environment and a stable society. Sustainable finance is defined as the provision of financial capital and risk management products to projects and businesses that promote, or do not harm, economic prosperity, environmental protection, and social justice (Mihir, Abdus and Shahriar, 2015). 


\subsubsection{E-mail Application Strategy}

E-mail is the transmission of messages over communications networks. Communicating by email is almost instantaneous, which enhances communications by quickly disseminating information and providing fast response to customer inquiries. It also allows for quicker problem-solving and more streamlined business processes. Email reduces geographic and time zone barriers for businesses. Employees or contractors from around the world can communicate, regardless of their location. Likewise, customers can send sales questions and support requests by email based on their own time zone schedules (Thompson, 2019). Email allows the financial institutions to targeted audiences. Financial institutions can communicate with established distribution lists, automatically forward information based on a topic, or send information to specific individuals as needed. Most email software provides customization features you can tailor to the type of work performed, volume of daily email messages and the needs of the worker. (Thompson, 2019). A significant business benefit from email is the ability to process incoming and outgoing messages automatically. Software can automatically file incoming emails by sender, content or subject. It can automatically respond to inquiries by sending confirmation notices and responses to messages. Software can also routinely send messages such as reminders, newsletters and statements without human intervention (Thompson, 2019).

\subsubsection{Global Talent Pool Strategy}

Global talent pool is an expression used to describe a database with all of your current and potential future job candidates. Talent Pool refers to a place or database where recruiters and HR Managers keep all of their top job candidates. Building talent pools with qualified candidates is important for many reasons, and some of the most important ones include reducing time to hire, improving quality of hire and reducing cost to hire (Ramona, 2013). The progressively dynamic nature of the workforce inside organizations is making it more difficult for organizations to attract, develop, and retain the best talent while simultaneously meeting the fiscal realities of the business. This is causing many organizations to move from a talent ownership mindset to a talent attraction mindset. In a talent ownership world, recruitment and the hiring transaction are king. But in a talent attraction world, successful organizations are those that master the art of building and maintaining talent communities that keep talent connected to the organization even when they are not employed by it(Ramona, 2013).

Consciously creating an external talent strategy is therefore essential to success. A talent pool is a database of potential job candidates that have the potential to meet an organization's immediate and long-term needs. In order to build a talent pool, HR managers must understand corporate goals as they relate to expected hires over the next several years. They must know whether training and mentoring efforts are strong enough to fill open positions internally and be able to identify actual, as well as potential, skills gap. A talent pool database should contain information about each prospect, including the person's skills, roles they could fill and whether they are a cultural fit. Internal organizational talent pools include employees who have the potential to learn new skills or advance with training and mentoring (Margaret, 2018).

\subsubsection{High Employee Engagement}

Employee engagement today has become synonymous with terms like 'employee experience' and 'employee satisfaction'. The relevance is much more due to the vast majority of new generation professionals in the workforce who have a higher propensity to be distracted and disengaged at work (Skinner, Elton, Auer, and Barbara, 2014). Employee engagement has emerged as a popular organizational concept in recent years. It has become one of the most 
leading priorities of human resource practitioners and senior managers in the organization today in the corporate world (Bhatla, 2011). Employee engagement has generated great deal of attention among many human resource practitioners, business entrepreneurs and academic researchers across the globe. Human resources are important assets of every organization. The success or failure of the organizations is largely dependent upon employees working in it (Khan, 2013). In this era of globalization and industrialization, where there is large scale competition in the market, it is necessary for the organization to have engaged workforce for the survival and smooth functioning of the organization. Employee engagement is considered as an important technique that is commonly used now a days in the corporate world, mainly in service industry.

Engaged employees are seen to be productive members of an organization who are psychologically committed to their role in the Organization. They are likely to stay longer in their organization, advocate its products and services and contribute to the overall success of an organization. David (2011) define employee engagement as "a positive attitude held by the employee towards the organization and its value. An engaged employee is aware of business context, and works with colleagues to improve performance within the job for the benefit of the organization. Therefore, the full engagement equation is obtained by aligning maximum job satisfaction and maximum job contribution. Organizations have become increasingly aware of the need to involve people through participation, empowerment, better access and opportunities to career advancement and proper ergonomics. A nation with abundance physical resources will not be benefited unless the human resources are effectively deployed and utilized to ensure they willingly employ and express themselves physically, cognitively and emotionally during their role performances. Employees are moving out of institutions and getting into others in search of better pay and benefits, effective communication where they clearly know what is expected of them and speedy responses provided to their grievances, better leadership that uphold healthy interrelationship between employees and leaders, and opportunities for developing their careers (HRM, 2016).

\subsubsection{Employee Retention}

Many organizations do not consider the factors determining employee retention as a strategy in managing competition and are likely to become victims of industry competition. The retention of employees has been shown to be significant to the development and the accomplishment of organization "s goals and objectives especially in building competitive advantage over other organization in the phase of increased globalization. Today, changes in technology, global economics, trade agreements, and the like are directly affecting employee/employer relationships thus leading to high employee turnovers thereby affecting employee retention in an organization( Ednah and Geoffrey, 2017)

Zineldin (2010) employee retention is the all-round module of an organization's human resource strategies, which commences with the recruitment of the right people with the right skills that is required by the organization and continues with practices which promotes employee engagement and commitment to the organization. Employee retention issues are emerging as the most critical workforce management challenges of the immediate future. Since the mid-1990s, scholarly research investigations have been focusing not only on determining why employees leave organizations but also concentrating on those factors positively influencing employees to stay as well as the benefits associated with retaining tenured workers (Ramlall, 2004). Effectively designed and well implemented employee retention programs that increase employee tenure more (Ramlall, 2014).In summary, the increasing significance of people to organisational success has been observed to have corresponded with the rise of strategic human resource management (SHRM) as a field of study on a global range. 


\subsection{Theoretical Review \\ Social Exchange Theory}

Saks (2006) proposed social exchange theory about employee engagement. The study rest on social exchange theory because it interprets society as a series of interactions between people that are based on estimates of rewards and punishments.Social exchange theory proposes that social behavior is the result of an exchange process. The purpose of this exchange is to maximize benefits and minimize costs. According to this theory, developed by sociologist George Homans, people weigh the potential benefits and risks of social relationships. When the risks outweigh the rewards, people will terminate or abandon that relationship (Kendra, 2019).

This theory provides a hypothetical basis to discuss why employees become more or less engaged towards their works. The proposal of social exchange theory is that obligations are made through a series of interactions between parties who are in a state of reciprocal interdependence. It is give and take relationship and perceived fairness between the two parties which dictates how successful the relationship is. Therefore one effective technique for an employee to pay their organization is through their level of engagement towards their work. Saks (2006) argued that the level of engagement of the employees is largely dependent upon the facilities and resources which they receive from their organization. By making full involvement towards their works and dedicating higher amount of cognitive and emotional and physical resources is an important way for every employee to respond to the organizational action (AbuKhalifeh \& Som, 2013).

\subsection{Empirical review}

Phillippa (2018) conducted a study on the effect of satisfaction and commitment on engagement of employees in Nigerian Banks. The study aims to ascertain the effect of satisfaction and commitment on engagement of employees in Nigerian banks with particular reference to First Bank Nigeria, PLC Asaba zone offices. Multiple regression analysis was deployed to test the various hypotheses formulated in the study. The result showed that less satisfaction of the employees resulted to high commitment on employee engagement to work better. The study recommended that managers should always proactively schedule one-on-one time with their employees.

Smith (2017) investigated on the management strategies to improve employee engagement in the credit union industry. The purpose of the study was to explore employee engagement strategies that credit union managers use to increase productivity and organizational effectiveness. The study made use of semi structured interviews and observations. The results of the study was to impact positive social change by improving the competitive environment of the credit union industry through engagement within community and society. The study concludes that demand to maintain relevancy in the credit union industry require managers to invest in employee engagement in order maintain the competitive advantage. The study recommended that managers should determine whether the strategies presented in this study align with existing strategies and make adjustments that would benefit productivity and organizational performance.

Nwigbo, Augustus-Daddie and Abbey-Kalio (2016) carried out a study on the assessment of talent management strategies in Nigerian Banking Industry: A study of selected Money Deposit Banks in Port Harcourt. this paper assessed the talent management strategies in Nigerian banking industry. The study adopted a survey design, and the study was conducted using a sample of 80 top and middle level management staff drawn from six banks in the Port Harcourt metropolis. The study shows that a careful mix of competitive strategy, human resource planning strategy and change management strategy should be adopted to avoid frequent organizational memory loss which at the long-run affects the performance of the 
organizations negatively. The study recommended that careful mix of competitive strategy, human resource planning strategy and change management strategy should be adopted in talent management to avoid frequent organizational memory loss which at the long-run affects the performance of the organization negatively.

Samson, Omotayo, Anthonia, Odunayo and Hezekiah (2016) investigated on the talent retention and organizational performance: A competitive positioning in Nigerian Banking Sector. The study examined how best an organization can retain and manage talented employees to ensure survival and growth in the banking industry. The descriptive research design was adopted. The results of the study showed that pay has positive significant implications on employees' commitment and involvement. The study recommended that decision makers should incorporate these variables (salary, bonus, incentives, reward, and profit sharing) into their employment relation strategies and policies which ultimately lead to increase the level of commitment and involvement among the employees.

Stanley and Oghoator (2015) examined on talent management and employees retention in Nigerian Universities. The purpose of the study was to examine the relationship between talent management and employee retention. The study employed primary source of data through administered questionnaires and Secondary sources of data were also used while reviewing related literature. Test of equality, Pearson correlation and ordinary least square regression techniques were utilized for the data analysis. The result indicated that performance management was significant and positively related to organizational culture. The study therefore recommended that universities should adopt a proactive performance management system to have a more transparent and dynamic institutional culture so as to encourage and retain skillful and talented employees.

Agwu, Atuma, Aigbiremolen and Iyoha (2015) conducted a study on the impact of information communication technologies in the strategic management of financial institutions. The study was to examined on the Impact of Information Communication Technologies on Strategic Management of Financial Institutions. The study adopted Qualitative research. Findings revealed that ICTs have indeed contributed a lot in improving the functioning of all departments of the selected banks such as marketing, operations, HR, finance, call centers, customer services, etc. The study recommends that through proper training, i.e. the provision of ICT related training to employees with respect to the strategic and operational management of the banks as well as exploration of the importance of the recruitment of external consultants who are specialized in their respective fields to render solid supports.

Stephen and Sibert (2014) investigated on the impact of mobile banking on financial inclusion in Zimbabwe: A case for Masvingo province. The purpose of the study was to examine the impact of mobile banking on financial inclusion in Zimbabwe. Financial inclusion is an urgent issue because of great numbers of 'unbanked' people in developing countries. The study adopted a qualitative research methodology and a survey design. The survey covered Masvingo district in Zimbabwe. The results revealed that the low income people are willing to adopt mobile banking and the reasons are that it is easily accessible, convenient, cheaper, easy to use and secure. The study recommended that there is need for the Central bank to supervise non-bank led mobile banking models and manage their cash holding limits and cost structures.

David and Adeola (2014) conducted a study on the influence of individual and organizational factors on employee engagement. The study examined the individual and organizational factors that influence employee engagement (EE) among employees of Nigeria Distilleries Limited in Ogun State of Nigeria. Simple random sampling technique was employed to obtain a sample of 174 employees of Nigeria Distilleries Limited, from whom responses were obtained using questionnaire. The findings showed a positive and significant relationships 
between work locus control, conscientiousness, openness to experience, leadership style, organizational climate, supervisory support; and employee engagement. The study recommended that managers should give attention to such factors that actually engender employee engagement towards organizational competitiveness.

\subsection{Methodology}

The survey approach was adopted because the respondents were spread all over the Institutions that make up the study organization; hence, the study was interested in obtaining their views through the use of questionnaire. The areas of study includes: the Zenith bank plc. United banks of Africa (UBA), ECObank, and First bank plc. The idea of choosing Enugu state was the proximity of these banks in Enugu metropolis. Two sources of data were utilized in the study. They included primary and secondary sources. The primary sources were personal interview and the administration of questionnaire. Out of a population of 560 staff and students, 218 staff was sampled. The sample size of 218 was chosen after applying the Freund and William's formula for the determination of adequate sample size. 214 staff returned the questionnaire and accurately filled. That gave 97 percent response rate. The closed-ended questionnaire was utilized. The validity of the instrument was tested using content analysis and the result was good. The reliability was tested using the Pearson correlation coefficient(r). It gave a reliability co-efficient of 0.89 which was also good. The data were analyzed using regression analysis and f-statistical tool aid of Special Package of Statistical Software (SPSS).

\subsection{Data Analysis and Presentation}

Research Question One: What is the effect of e-mail application strategy on the low costs of financial institution in Nigeria?

Table 4.1: Responses to research question one: on the effect of e-mail application strategy on the low costs of financial institution in Nigeria

\begin{tabular}{|c|c|c|c|c|c|c|c|c|c|c|}
\hline & & $\begin{array}{l}\mathbf{5} \\
\text { SA }\end{array}$ & $\begin{array}{l}4 \\
\mathbf{A}\end{array}$ & $\begin{array}{l}\mathbf{3} \\
\mathbf{N}\end{array}$ & $\begin{array}{l}2 \\
\text { DA }\end{array}$ & $\begin{array}{l}1 \\
\text { SD }\end{array}$ & $\sum \mathbf{F X}$ & $\overline{\mathbf{X}}$ & SD & Decision \\
\hline 1 & $\begin{array}{l}\text { My institution has been } \\
\text { engaged in e-mail } \\
\text { application strategy }\end{array}$ & $\begin{array}{l}100 \\
20\end{array}$ & $\begin{array}{l}456 \\
114\end{array}$ & $\begin{array}{l}81 \\
27\end{array}$ & $\begin{array}{l}64 \\
32\end{array}$ & $\begin{array}{l}21 \\
21\end{array}$ & $\begin{array}{l}722 \\
214\end{array}$ & 3.37 & 1.147 & Agree \\
\hline 2 & $\begin{array}{l}\text { The e-mail application } \\
\text { strategy has reduced insider } \\
\text { abuse in my organization }\end{array}$ & $\begin{array}{l}700 \\
140\end{array}$ & $\begin{array}{l}156 \\
39\end{array}$ & $\begin{array}{l}36 \\
12\end{array}$ & $\begin{array}{l}20 \\
10\end{array}$ & $\begin{array}{l}13 \\
13\end{array}$ & $\begin{array}{l}925 \\
214\end{array}$ & 4.32 & 1.160 & Agree \\
\hline 3 & $\begin{array}{l}\text { The use of e-mail } \\
\text { application reduced the } \\
\text { expenses of paper } \\
\text { documentation }\end{array}$ & $\begin{array}{l}305 \\
61\end{array}$ & $\begin{array}{l}288 \\
72\end{array}$ & $\begin{array}{l}75 \\
25\end{array}$ & $\begin{array}{l}36 \\
18\end{array}$ & $\begin{array}{l}38 \\
38\end{array}$ & $\begin{array}{l}742 \\
214\end{array}$ & 3.47 & 1.436 & Agree \\
\hline 4 & $\begin{array}{l}\text { The cost of external } \\
\text { consultants have been by }\end{array}$ & $\begin{array}{l}480 \\
96\end{array}$ & $\begin{array}{l}169 \\
40\end{array}$ & $\begin{array}{l}75 \\
25\end{array}$ & $\begin{array}{l}70 \\
35\end{array}$ & $\begin{array}{l}18 \\
18\end{array}$ & $\begin{array}{l}812 \\
214\end{array}$ & 3.79 & 1.387 & Agree \\
\hline
\end{tabular}
the e-mail application

\section{Total grand mean and} standard deviation

\section{Source: Field Survey, 2019}

Table 4.1 indicated that the institutions have been engaged in e-mail application strategy with mean score of 3.37 from the respondents and standard deviation of 1.147. The e-mail application strategy has reduced insider abuse in the organization with 4.32 agree of mean score and standard deviation of 1.160. The use of e-mail application reduced the expenses of paper documentation with 3.47 mean score and 1.436 standard deviation. The costs of 
external consultants have been by the e-mail application with mean score of 3.79 and standard deviation of 1.387 .

Research Question Two: What is the effect of online application strategy on the employee engagement of financial institution in Nigeria?

Table 4.2: Responses to Research Question Two: on the effect of online application strategy on the employee engagement of financial institutions in Nigeria.

\begin{tabular}{|c|c|c|c|c|c|c|c|c|c|c|}
\hline & & $\begin{array}{l}\mathbf{5} \\
\text { SA }\end{array}$ & $\begin{array}{l}4 \\
\mathbf{A}\end{array}$ & $\begin{array}{l}\mathbf{3} \\
\mathbf{N}\end{array}$ & $\begin{array}{l} \\
\text { DA }\end{array}$ & $\begin{array}{l}1 \\
\text { SD }\end{array}$ & $\sum \mathbf{F X}$ & $\overline{\mathbf{X}}$ & SD & Decision \\
\hline 1 & $\begin{array}{l}\text { Online application form } \\
\text { strategy attracted better } \\
\text { employees in financial } \\
\text { institution was due to } \\
\text { online application. }\end{array}$ & $\begin{array}{l}390 \\
78\end{array}$ & $\begin{array}{l}448 \\
112\end{array}$ & $\begin{array}{l}66 \\
22\end{array}$ & $\begin{array}{l}2 \\
1\end{array}$ & $\begin{array}{l}1 \\
1\end{array}$ & $\begin{array}{l}907 \\
214\end{array}$ & 4.24 & .688 & Agree \\
\hline 2 & $\begin{array}{l}\text { High productivity in my } \\
\text { financial institution due } \\
\text { online application. }\end{array}$ & $\begin{array}{l}770 \\
154\end{array}$ & $\begin{array}{l}156 \\
39\end{array}$ & $\begin{array}{l}15 \\
5\end{array}$ & $\begin{array}{l}24 \\
12\end{array}$ & $\begin{array}{l}4 \\
4\end{array}$ & $\begin{array}{l}969 \\
214\end{array}$ & 4.52 & .928 & Agree \\
\hline 3 & $\begin{array}{l}\text { The conscientiousness of } \\
\text { the employees was result } \\
\text { of online application. }\end{array}$ & $\begin{array}{l}285 \\
57\end{array}$ & $\begin{array}{l}316 \\
79\end{array}$ & $\begin{array}{l}87 \\
29\end{array}$ & $\begin{array}{l}36 \\
18\end{array}$ & $\begin{array}{l}31 \\
31\end{array}$ & $\begin{array}{l}755 \\
214\end{array}$ & 3.52 & 1.352 & Agree \\
\hline 4 & $\begin{array}{l}\text { Online application form } \\
\text { enhanced the increased } \\
\text { openness to experience. }\end{array}$ & $\begin{array}{l}485 \\
97\end{array}$ & $\begin{array}{l}224 \\
56\end{array}$ & $\begin{array}{l}66 \\
22\end{array}$ & $\begin{array}{l}58 \\
29\end{array}$ & $\begin{array}{l}10 \\
10\end{array}$ & $\begin{array}{l}843 \\
214\end{array}$ & 3.94 & 1.234 & Agree \\
\hline & $\begin{array}{l}\text { Total grand mean and } \\
\text { standard deviation }\end{array}$ & & & & & & & 4.06 & 1.051 & \\
\hline
\end{tabular}

Source: Field Survey, 2019

Table 4.2 indicated that online application form strategy attracted better employees in financial institution was due to online application with mean score of 4.24 from the respondents and standard deviation of .688. High productivity in my financial institution due online application with 4.52 agrees of mean score and standard deviation of .928. The conscientiousness of the employees was result of online application with 3.52 mean score and 1.352 standard deviation. Online application form enhanced the increased openness to experience with mean score of 3.94 and standard deviation of 1.234.

\subsection{Test of Hypotheses}

Hypothesis One:

E-mail application forms strategy has positive significant effect on the low cost of financial institutions in Nigeria.

Model Summary

\begin{tabular}{|l|r|r|r|r|}
\hline Model & R & R Square & $\begin{array}{c}\text { Adjusted R } \\
\text { Square }\end{array}$ & $\begin{array}{c}\text { Std. Error of the } \\
\text { Estimate }\end{array}$ \\
\hline 1 & $.762^{\mathrm{a}}$ & .738 & .727 & .48978 \\
\hline
\end{tabular}

a. Predictors: (Constant), MYI, THE, USE, COS

ANOVA $^{\mathrm{a}}$

\begin{tabular}{|ll|r|r|r|r|c|}
\hline Model & & Sum of Squares & df & Mean Square & F & Sig. \\
\hline \multirow{4}{*}{1} & Regression & 39.009 & 4 & 9.752 & 40.654 & $.000^{\mathrm{b}}$ \\
& Residual & 50.136 & 209 & .240 & & \\
& Total & 89.145 & 213 & & & \\
\hline
\end{tabular}

a. Dependent Variable: EFF

b. Predictors: (Constant), MYI, THE, USE, COS. 
Where

$\mathrm{EFF}=$ Effect of e-mail application form strategy on the low cost of financial institutions in Nigeria

MYI = My institution has been engaged in e-mail application strategy.

THE = The e-mail application strategy has reduced insider abuse in my organization

USE $=$ The use of e-mail application reduced the expenses of paper documentation

$\operatorname{COS}=$ The cost of external consultants have been by the e-mail application

\section{STATISTICAL CRITERIA \{FIRST ORDER TEST\}}

\section{COEFFICIENT OF MULTIPLE DETERMINANTS $\left\{\mathbf{R}^{2}\right\}$}

The $\mathrm{R}^{2}\{\mathrm{R}$-Squared $\}$ which measures the overall goodness of fit of the entire regression, shows the value as 0.738 and adjusted to 0.727 . This means that $R^{2}$ accounts for 73.8 percent approximately 74 percent. This indicates that the independent variables accounts for about 74 percent of the variation in the dependent variable. Which shows goodness of fit.

\section{F-STATISTICS (ANOVA)}

The F-statistics is used to test for simultaneous significance of all the estimated parameters.

The hypothesis is stated;

$\mathrm{H}_{0}: \beta_{1}=\beta_{2}=\beta_{3}=\beta_{4}$ (Responses on whether engaged in e-mail application, Insider abuse, reduced expenses paper documentation, cost of external consultants have no significant effect on the on the low cost of financial institutions in Nigeria.

$\mathrm{H}_{1}: \beta_{1} \neq \beta_{2} \neq \beta_{3} \neq \beta_{4}$ (Responses on whetherengaged in e-mail application, Insider abuse, reduced expenses paper documentation, cost of external consultants have no significant effect on the on the low cost of financial institutions in Nigeria.

Level of significance: $\alpha$ at $5 \%$

Degree of freedom: $\quad \frac{\mathrm{K}-1}{\mathrm{~N}-\mathrm{K}}=\frac{5-1}{214-5}=(209,4)=3.1161$

\section{Decision Rule:}

If the F- calculated is greater than the F-tabulated $\{\mathrm{F}-\mathrm{cal}>\mathrm{F}-\mathrm{tab}\}$ reject the null hypothesis $\left\{\mathrm{H}_{0}\right\}$ that the overall estimate is not significant and conclude that the overall estimate is statistically significant. From the result, F-calculated $\{40.654\}$ is greater that the F-tabulated $\{3.1161\}$, that is, F-cal > F-tab. Hence, we reject the null hypothesis $\left\{\mathrm{H}_{0}\right\}$ and accept Alternative hypothesis which means that the overall estimate has a good fit which also implies that our independent variables are simultaneously significant. We now conclude from the analysis thate-mail application forms strategy has positive significant effect on the low cost of financial institutions in Nigeria.

\section{Hypothesis Two}

Online application forms strategy has positive significant effect on the high employee engagement of financial institution in Nigeria

$$
\text { Model Summary }
$$

\begin{tabular}{|l|r|r|r|r|}
\hline Model & R & R Square & $\begin{array}{c}\text { Adjusted R } \\
\text { Square }\end{array}$ & $\begin{array}{c}\text { Std. Error of the } \\
\text { Estimate }\end{array}$ \\
\hline 1 & $.725^{\mathrm{a}}$ & .725 & .716 & .50928 \\
\hline
\end{tabular}

a. Predictors: (Constant), APP, HIG, CON, FOR 


\begin{tabular}{|rl|r|r|r|r|r|}
\hline Model & & Sum of Squares & \multicolumn{1}{|c|}{ Df } & Mean Square & \multicolumn{1}{c|}{ F } & \multicolumn{1}{c|}{ Sig. } \\
\hline \multirow{2}{*}{1} & Regression & 60.026 & 4 & 15.007 & 57.857 & $.000^{\mathrm{b}}$ \\
& Residual & 54.209 & 209 & .259 & & \\
& Total & 114.235 & 213 & & & \\
\hline
\end{tabular}

a. Dependent Variable: ONLI

b.Predictors: (Constant), APP, HIG, CON, FOR

Where

ONLI $=$ Effect of online application form strategy on the high employee engagement of financial institution in Nigeria.

$\mathrm{APP}=$ Online application form strategy attracted better employees in financial institutionwas due to online application

HIG = High productivity in my financial institution due online application

$\mathrm{CON}=$ The conscientiousness of the employees was result of online application.

FOR $=$ Online application form enhanced the increased openness to experience

\section{STATISTICAL CRITERIA \{FIRST ORDER TEST\}}

\section{COEFFICIENT OF MULTIPLE DETERMINANTS $\left\{\mathbf{R}^{2}\right\}$}

The $\mathrm{R}^{2}\{\mathrm{R}$-Squared $\}$ which measures the overall goodness of fit of the entire regression, shows the value as 0.725 and adjusted to 0.716 . This means that $\mathrm{R}^{2}$ accounts for 72.5 percent approximately 73 percent. This indicates that the independent variable accounts for about 73 percent of the variation in the dependent variable. Which shows goodness of fit?

\section{F-STATISTICS (ANOVA)}

The F-statistics is used to test for simultaneous significance of all the estimated parameters. The hypothesis is stated;

$\mathrm{H}_{0}: \quad \beta_{1}=\beta_{2}=\beta_{3}=\beta_{4}$ (Responses on whetherattracts better employees, high productivity, conscientiousness employees and increased openness to experience have no positive significant effect on the high employee engagement of financial institution in Nigeria

$\mathrm{H}_{1}: \quad \beta_{1} \neq \beta_{2} \neq \beta_{3} \neq \beta_{4}$ (Responses on whetherattracts better employees, high productivity, conscientiousness employees and increased openness to experience have positive significant effect on the high employee engagement of financial institution in Nigeria Level of significance: $\alpha$ at $5 \%$

Degree of freedom: $\quad \frac{\mathrm{K}-1}{\mathrm{~N}-\mathrm{K}}=\frac{5-1}{214-5}=(209,4)=3.1161$

\section{Decision Rule:}

If the F-calculated is greater than the F-tabulated $\{\mathrm{F}-\mathrm{cal}>\mathrm{F}-\mathrm{tab}\}$ reject the null hypothesis $\left\{\mathrm{H}_{0}\right\}$ that the overall estimate is not significant and conclude that the overall estimate is statistically significant. From the result, F-calculated $\{57.857\}$ is greater that the f-tabulated $\{3.1161\}$, that is, F-cal > F-tab. Hence, we reject the null hypothesis $\left\{\mathrm{H}_{0}\right\}$ and accept Alternative hypothesis which means that the overall estimate has a good fit which also implies that our independent variables are simultaneously significant. We now concluded from the analysis thatonline application forms strategy has positive significant effect on the high employee engagement of financial institution in Nigeria 


\section{Hypothesis Three:}

Global talent pool application forms strategy has positive significant effecton the high employee retention of financial institutions in Nigeria.

Model Summary

\begin{tabular}{|l|r|r|r|r|}
\hline Model & R & R Square & $\begin{array}{c}\text { Adjusted R } \\
\text { Square }\end{array}$ & $\begin{array}{c}\text { Std. Error of } \\
\text { the Estimate }\end{array}$ \\
\hline 1 & $.712^{\mathrm{a}}$ & .707 & .707 & .45871 \\
\hline
\end{tabular}

a. Predictors: (Constant), CRE, TAL, TER, HIH

ANOVA $^{\mathrm{a}}$

\begin{tabular}{|rl|r|r|r|r|r|}
\hline \multicolumn{1}{|l|}{ Model } & \multicolumn{1}{|c|}{$\begin{array}{c}\text { Sum of } \\
\text { Squares }\end{array}$} & \multicolumn{1}{c|}{ Df } & Mean Square & F & Sig. \\
\hline \multirow{3}{*}{1} & Regression & 45.168 & 4 & 11.292 & 53.666 & $.000^{\mathrm{b}}$ \\
& Residual & 43.976 & 209 & .210 & & \\
& Total & 89.145 & 213 & & & \\
\hline
\end{tabular}

a. Dependent Variable: GLO

b. Predictors: (Constant), CRE, TAL, TER, HIH

Where

GLO = Effect of global talent pool application form strategy on the high employee retention of financial institutions in Nigeria

$\mathrm{CRE}=$ My financial institutions creates forum for job that can meet up for our organisations immediate needs

TAL = Talent pool in my organisation focus on the people who are capable of performing a variety of job tasks

TER = There is cost effective of recruitment in my organisation that improved the quality of staff

$\mathrm{HIH}=$ High quality job candidates are attracted during global talent pool that improved the selection of candidates

\section{STATISTICAL CRITERIA \{FIRST ORDER TEST\}}

\section{COEFFICIENT OF MULTIPLE DETERMINANTS $\left\{\mathbf{R}^{2}\right\}$}

The $\mathrm{R}^{2}\{\mathrm{R}$-Squared $\}$ which measures the overall goodness of fit of the entire regression, shows the value as 0.707 and adjusted to 0.707 . This means that $\mathrm{R}^{2}$ accounts for 70.7 approximately 71 percent. This indicates that the independent variables accounts for about 71 percent of the variation in the dependent variable. Which shows goodness of fit?

\section{F-STATISTICS (ANOVA)}

The F-statistics is used to test for simultaneous significance of all the estimated parameters. The hypothesis is stated;

$\mathrm{H}_{0}: \beta_{1}=\beta_{2}=\beta_{3}=\beta_{4}$ (Responses on whethercreates forum for job seekers, people who are capable of performing, cost effectiveness, high quality job candidates have no positive significant effect on the high employee retention of financial institutions in Nigeria.

$\mathrm{H}_{1}: \beta_{1} \neq \beta_{2} \neq \beta_{3} \neq \beta_{4}$ (Responses on whetherCreates forum for job seekers, people who are capable of performing, cost effectiveness, high quality job candidates have positive significant effect on the high employee retention of financial institutions in Nigeria.

Level of significance: $\alpha$ at 5\%

Degree of freedom: $\quad \frac{\mathrm{K}-1}{\mathrm{~N}-\mathrm{K}}=\frac{5-1}{214-5}=(209,4)=3.1161$ 


\section{Decision Rule:}

If the F-calculated is greater than the F-tabulated $\{\mathrm{F}$-cal $>\mathrm{F}$-tab $\}$ reject the null hypothesis $\left\{\mathrm{H}_{0}\right\}$ that the overall estimate is not significant and conclude that the overall estimate is statistically significant. From the result, f-calculated $\{53.666\}$ is greater that the F-tabulated $\{3.1161\}$, that is, F-cal > F-tab. Hence, we reject the null hypothesis $\left\{\mathrm{H}_{0}\right\}$ and accept Alternative hypothesis which means that the overall estimate has a good fit which also implies that our independent variables are simultaneously significant. We now concluded from the analysis thatglobal talent pool application forms strategy has positive significant effect on the high employee retention of financial institutions in Nigeria.

\subsection{Discussion of findings}

4.2.1 E-mail application forms strategy has positive significant effect on the low cost of financial institutions in Nigeria.

The result of hypothesis one, F-calculated $\{40.654\}$ is greater that the F-tabulated $\{3.1161\}$, that is, F-cal > F-tab. We now conclude from the analysis thate-mail application forms strategy has positive significant effect on the low cost of financial institutions in Nigeria. In the support of the above result in the literature review, Agwu, Atuma, Aigbiremolen and Iyoha (2015), financial institutions identified the internet as a major opportunity to tackle distribution costs and to reengineer the structure of the industry and that quality customer service differentiates one financial institution from the other and helps secure customer loyalty. For this purpose, precise data related to the customers is necessary for customizing services and enhancing the advantage of marketing program and only those financial originations that can become successful are those that can continuously reduce their costs and improve their products by obtaining a convincing existence in the major financial markets (Agwu, Atuma, Aigbiremolen and Iyoha, 2015).

\subsubsection{Online application forms strategy has positive significant effect on the high employee engagement of financial institution in Nigeria.}

The result of hypothesis two, F-calculated $\{57.857\}$ is greater that the f-tabulated $\{3.1161\}$, that is, F-cal > F-tab. We now concluded from the analysis thatonline application forms strategy has positive significant effect on the high employee engagement of financial institution in Nigeria. In the support of the result, David and Adeola (2014), employee engagement is a strategic approach for driving improvement and encouraging organizational change. In line with Smith (2017) managers value the findings of the study because employee engagement is critical to the sustainability of the organization and organization may improve because expanding managers' knowledge of engagement strategies will help managers keep staff engaged and increase productivity therefore, gaining maintaining employees engagement can help other managers increase organizational performance by reducing and eliminating the number of disengaged employees.

\subsubsection{Global talent pool application forms strategy has positive significant effecton the high employee retention of financial institutions in Nigeria.}

The result of hypothesis three, F-calculated $\{53.666\}$ is greater that the F-tabulated $\{3.1161\}$, that is, F-cal > F-tab. We now concluded from the analysis thatglobal talent pool application forms strategy has positive significant effect on the high employee retention of financial institutions in Nigeria. In support of the result, Stanley and Oghoator (2015) organizations are run by people, processes, technology and capital but it is the aspect of the human side of the organization that makes decision. The quality of employees at the disposal of an organization determines result. Talent management is based on the fact organizations are run by people. Processes, technology and capital are important, but it is people who make the 
decisions. It therefore follows that the quality of employees at the disposal of an organization determines productivity. The competitive nature of Nigerian universities environment and shortage in the number of competent people has made it important for them to attract, retain and motivate highly skilled employees.

\subsection{Conclusion}

The purpose of the study was to evaluate the green recruitment strategy on the economic sustainability of financial institutions in Nigeria, economic development is the desire of all nations of the world but how to attain a sustainable economic development remains a challenge to many nations. A sustainable economic in financial institution requires sustainable enterprises that requires a new way to carry out the green recruitment strategy in the financial institution in the economy. The study requires the strategies of the financial institutions become greener in their operations as well as a new and clean environmental technologies with some other specialization while engaging employees in making use of online application. A new way of economic life that will empower Nigerians to meet their needs and still be able to conserve the resources for present and future generations is needed. In conclusion, the result showed that e-mail application forms strategy has positive significant effect on the low cost of financial institutions in Nigeria. Online application forms strategy has positive significant effect on the high employee engagement of financial institution in Nigeria. Global talent pool application forms strategy has positive significant effect on the high employee retention of financial institutions in Nigeria.

\subsection{Recommendations}

The attainment of green recruitment strategy on the economic sustainability requires a sustainable economic development strategy. To this end, the following recommendations are made:

1. The management team should show recognition and appreciation for work well done as this may assist in employee retention and enhance the culture of the financial institutions.

2. The management team should identify other variables other than compensation reward that will assist in retaining employees and in building a dynamic organizational sustainability.

\section{REFERENCES}

1. AbuKhalifeh, A. N.\& Som, A. P. M. (2013). The antecedents affecting employee engagement and organizational performance. Asian Social Science, 9(7), 41- 46.

2. Adam, H. (2019). Financial institution (FI).https://www.investopedia.com/terms/f/financi alinstitution.asp.

3. Aranganathan, P. (2018). Green recruitment: A newfangled approach to attract and retain talent.International Journal of Business Management \& Research, 8(2); 69-76.

4. Aruljah, A., Opatha, H. H., \& Nawaratne, N. N. (2015). Green human resource management practices: A review. Sri Lankan Journal of Human Resource Management, 5(1);1-16.

5. Bhatla, N. (2011). Employee engagement practices and its effects on employee performance with special reference to ICICI and HDFC bank in Lucknow. International Journal of Scientific \& Engineering Research, 2(8), 1 - 7.

6. David, O. A. and Adeola, A. O. (2014). The influence of individual and organizational factors on employee engagement.International Journal of Development and Sustainability, 3(6); 1381-1392. 
7. David. C (2011).Employee Engagement. Approach to building a Business. Moonstone media.

8. Dutta, S. (2012). Greening people: A strategic dimension. ZENITH International Journal of Business Economics \& Management Research, 2(2), 143-148.

9. Human Resources. (2016). Research: Employee engagement ROI-rules of engagement [Online] Available: http://global.factiva.com/ ha/default.aspx. (October 28, 2017).

10. Kanu, C. and Isu, G (2015). Microfinance Banks operations in Nigeria, Constraints and Suggested Solutions: An Evaluation. Global Journal of Contemporary Research in Accounting, Auditing and Business Ethics, 1(2); 1-20.

11. Kendra, C. (2019). Understanding social exchange theory psychology. https://www.very wellmind.com/what-is-social-exchange-theory-2795882.

12. Khan, N. (2013). Human resource policies and practices in hospitality industry in India: A case study of selected hotels. (Doctoral dissertation). Aligarh Muslim University, Aligarh.

13. Kiruthigaa, K. and Viswanathan, M. (2014). A study on awareness of green recruitment with special reference to general public. International Journal of Research and Development - A Management Review, 3(2);1-4.

14. Margaret, R. 2018). Talent pool. https://searchhrsoftware.techtarget.com/definition/talentpool.

15. Mihir, K. R., Abdus, S. S. and Shahriar, P. 2015). Sustainability in Banking Industry: Which way to move? ASA University Review, 9(2);1-18.

16. Nwigbo T.S; Augustus-Daddie, J. and Abbey-Kalio, B. (2016). Assessment of talent management strategies in Nigerian Banking Industry: A study of selected Money Deposit Banks in Port Harcourt. Advance Research Journal of Multi-Disciplinary Discoveries, $1(1) ; 1-5$.

17. Olaf, W. (2014). The financial sector's impact on sustainable development. https://www.r esearchgate.net/publication/263764473_The_financial_sector's_impact_on_sustainable_d evelopment

18. Saks, A. M. (2006). Antecedents and consequences of employee engagement. Journal of Managerial Psychology, 21(7), 600-619.

19. Samson, I; Omotayo, O; Anthonia, A; Odunayo, P. S. and Hezekiah, F. (2016). Talent retention and organizational performance: A competitive positioning in Nigerian Banking Sector. Periodica Polytechnica Social and Management Sciences, 24(1),1-13.

20. Sharma, P. and Robin, N. (2011). Green recruitment. http://www.indianmba.com/Faculty Column/FC1333/fc1333.html.

21. Skinner, N; Elton, J; Auer, J. and Barbara, P. (2014). Understanding and managing worklife interaction across the life course: a qualitative study. Asia Pacific Journal of Human Resources, 52 (1); 93-109.

22. Smith, J. (2014).5 steps to a green recruiting strategy. https://eco-officegals.com/5-stepsgreen-recruiting-strategy/.

23. Smith, J.K. (2017). Management strategies to improve employee engagement in the credit union industry. Walden Dissertations and Doctoral Studies, 1-146.

24. Stanley, A. and Oghoator, I. H. (2015). Talent management and employees retention in Nigerian Universities. NG-Journal of Social Development, 5(1);1..9.

25. Stephen,M. and Sibert, C. (2014). The impact of mobile banking on financial inclusion in Zimbabwe: A Case for Masvingo Province. Mediterranean Journal of Social Sciences, 5(9);1-10.

26. Sudin, S. (2011). Strategic Green HRM: A proposed model that supports Corporate Environmental Citizenship. 2011 International Conference on Sociality and Economics Development IPEDR vol.10 (2011). IACSIT Press, Singapore 
27. Tang, G., Chen, Y., Jiang, Y., Paille, P.\& Jia, J. (2018). Green human resource management practices: Scale development and validity. Asia Pacific Journal of Human Resources, 56, 31-55.

28. Thompson, J. (2019). The advantages of email in business communication. https://smallb usiness.chron.com/advantages-email-business-communication-122.html. 